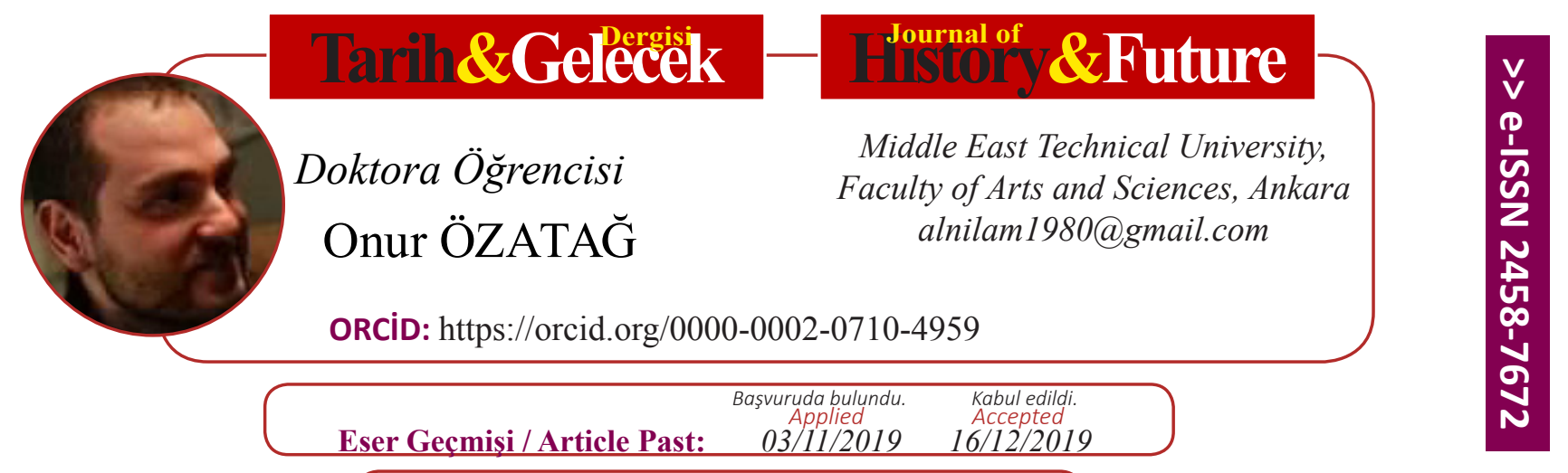

\title{
Suudi Arabistan'da Din, Siyaset ve Edebiyat:Güncel Dini ve Kültür-Politik Durumun Entelektüel Tarihsel Geçmişi
}

\author{
Religion, Politik und Literatur in Saudi-Arabien: Der \\ Geistesgeschichtliche Hintergrund der Heutigen Religiösen und \\ Kulturpolitischen Situation (III)
}

$\ddot{O} z$

Modern Suudi Arabistan üzerine günümüz Türkçe akademik literatürü derinlemesine ve güncel bir bilgi-tahlil birikimi sunmaktan ne yazı ki uzaktır. Öte yandan mevcut literatür ya bir karşı propaganda şeklindedir ya da sı̆̆ incelemelerden oluşmaktadır. Yine de bu, konu üzerine önemli eserlerin hiç var olmadığ anlamina gelmez. Kronolojik bir sıra ile akla ilk gelenler Eyüp Sabri Paşa'nın Tarih-i Vehhâbiyan'ı (1879), Yusuf Ziya Yörükhan 'ın "Vahhabîlik" (1953) adlı makalesi, Hüseyin Hilmi Işık’ın Vehhâbîye Nasihat'i (1981), Zekeriya Kurşun'un Necid ve Ahsa'da Osmanlı Hâkimiyeti: Vehhabî Hareketi ve Suud Devleti'nin Ortaya Çıkışı (1998) adlı kitabı ve son olarak Selda Güner'in Osmanlı Arabistan'ında Kıyam ve Tenkil: Vehhâbî-Suûdîler (1744-1819) adlı 2012 tarihli çalışmasıdır. Son tahlilde, eldeki makalenin modern Suudi Arabistan'ın dünyaya açıllş serüveni, ülkede süregiden entelektüel ve siyasi tartışmalar ve bunların, özellikle Arapça konuşan ülkelerde ve dünyada 1960larda uyandırdığı yankılar hususunda Türkçe literatürde önemli bir boşluğu dolduracağına inanılmaktadır.

Anahtar Kelimeler: Suudi Arabistan, Vahhabilik ve Modern Bilim, Suudlar-Nasircllık-Firavunculuk, Arap Milliyetçiliği.

* Bu makale, Orient 22 (1981) 3 ve 23 (1982) 1'de yayımlanmış olan makalelerin devamıdır.

Eserin künyesi

Ende, Werner: "Religion, Politik und Literatur in Saudi-Arabien: Der geistesgeschichtliche Hintergrund der Heutigen Religiösen und Kulturpolitischen Situation (III). In Orient. Deutsche Zeitschrift für Politik und Wirtschaft des Orients. 23 (3). 1982. pp. 378-393 


\section{Eski Vahhabilik ve Modernizm: Şeyh Abdulazīz İbn Bāz'ın Rolü}

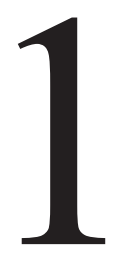
962 yılında, Suudi diplomat ve yazar Fahd el-Mārik (1910'da Hail'de doğmuştur) ${ }^{1}$ Şam'da Lemahāt 'an et-tatavvur el-fikrī fì cezīret el-arab fì'l-karn el-işrīn ("20. Yüzyıl Arap Yarımadası'nda Düşünsel Gelişime Bakışlar”) başlığı taşıyan bir kitap yayımladı. İthaf kısmının en başında kurucu kral İbn Suud'un (ö. 1953) ismi anılan bu kitap, Arap Yarımadası ülkelerinde ve özellikle de Suudi Arabistan'daki toplumsal ve kültürel yaşamın belirli yorumları üzerine sadık ve yapıcı bir eleştiri sunma girişimini temsil etmekte; bir parlamento oluşumu, parti sisteminin kabulü, hukuki muhalefet olasılığı, millileşme (te 'mim), belirli ekonomik meseleler vb. gibi fikir ve taleplerin artıları ve eksileri üzerine özgür ve derin bir tartışmaya duyulan ihtiyaca dair pek çok yorum içermektedir. ${ }^{2}$ Yazar, Suudi Arabistan'daki kültürel gelişimi betimlemek için aşağıdaki dönemlendirmeyi kullanmaktadır:

1) Yüzyılın başından ilk çeyreğin sonuna, yani Hicaz'da iktidarın ele geçirilişine kadar (1924-26)

2) 1927 'den 1950 'ye

3) 1950’den kitabın yazıldı̆̆ 1 zamana kadar, 1961/62

Onun için sonraki aşamayı, pek çok bölgede reformlara yönelik büyük oranda olumlu gelişmeler şekillendirecektir, öte yandan el-Mārik, Vahhabi ulemasının rolünü şüphe ile karşıladığ gerçeğini de gizlememekte ve bu aşamada, ülkenin reform güçleri tarafindan modernleştirilmesinin daha tutarlı bir şekilde sürdürülemeyeceği hususunda onları en azından ortak sorumlu olarak görmektedir. Ne var ki, ulemanın, ilerici eleştirilere karşı yaptırımlar uygulama gücünün azaldığını ve kendisin de bunu gördügünü okuyucuya açıkça söylemektedir. Örnek olarak da Suudi alim, gazeteci ve yayıncı Hamad el-Yāsir'in (doğ. 1911) yaşamında iki kez ulemanın hoşgörüsüzlügünü tecrübe edişinden bahsetmektedir: O, 1943 yılında, kadılık görevini bırakmasının ardından, tamamıyla siyaset dışı bir nedenle hapse atılmış, herhangi bir akrabası ya da önemli bir kişinin ziyareti olmaksızın, on dört gün boyunca, oldukça kötü şartlar altında hücrede kalmıştır. 1959 yılında, haftalık gazete el-Yemāme'de (Riyad, 1953'te onun tarafindan kurulmuştur) bir makalesinden rahatsız olan ulemanın talebi üzerine, bir defa daha tutuklandığında ise sadece üç ya da dört günün ardından tekrar serbest bırakılmış ve tutuklu kaldığı bu kısa zaman zarfında, (Suudi ailesinden) baz1 veliahtlar ve önde gelen kamu görevlileri de dahil olmak üzere iki yüzün üzerinde kişi tarafından ziyaret edilmiştir. Hal bu ki, erken dönemde böyle bir şey düşünülemezdi ve ölümle sonuçlanırdı. Bu tip ayrıntılar Suudi Arabistan'daki entelektüel gelişimin olumlu boyutlarını sergilemektedir. ${ }^{4}$

1 Tam adı Fahd ibn Mārik ibn Abdu'l-Azīz. Hal tercümesi için Ethem el-Cundī: A'lâm el-edeb ve’l-fenn, II, Şam 1958, s. 510, ayrıca Bekrî Şeyh Emîn: el-hareke el-edebîye fi'l-Memleke el-'Arabiye es-Su'ūdīye, Beirut 1972, s. 604 dipnot 3.

2 Lemahāt, özl. bkz. son bölüm (kurgusal bir diyalogdur) s. 183 ve dev.

3 Hal tercümesi için Bekrī Şeyh Emīn, s. 116 (dipnot 2), ayrıca es-Sāsī: el-mevsū’a (bkz. dipnot 54), s. 119-27. - Yayınevi Dar el-Yemāme’yi yıllarca Beyrut'tan yöneten ve ‘el-Arab' adlı dergisini yeniden düzenleyen Hamad el-Yāsir, 1970’lerin sonunda Riyad Üniversitesi’ndeki Arap Yarımadası Tarihsel Coğrafya Bölümü'ne Onursal Profesör olarak atanmıştır.

4 Lemahāt, s. 136-138 
Fahd el-Mārik, Hamad el-Yāsir'in örneği ile bağlantılı olarak, ona karşı dava açmış olan herhangi bir ulemanın adını zikretmez. Diğer yandan kitabın başka bir yerinde, yukarıda bahsettiğimiz ilahiyatçı Abdulaziz İbn Bāz'ın adı belirgin bir şekilde geçmektedir. ${ }^{5} \mathrm{Bu}$ - el-Mārik'ten iki yaş genç ve onun gibi Suudi Arabistan müftüsünün bir öğrencisi olan Muhammed İbn İbrahim (ö. 1969, Muhammed İbn 'Abdu'l-Vahhāb'ın soyundandır) ${ }^{6}$ - el-Mārik tarafından, İslam'da kölelik sorunu olarak 1953'te çoktan tartışılmıştı. Cevap mektubu, Fahd el-Mārik tarafindan, tıpkıbasım halinde kitabın başlangıç kısmına yerleştirilmiştir; burada İbn Bāz, gayri Müslimlerin köleliğinin (istirkāk) ancak çok belirli şartlar altında (yani cihat durumunda) caiz olduğunu ilan etmektedir. Ayrıca Fahd el-Mārik, okuyucu için kitabın arasına (manası müphem?) bir not da koymuştur: 'İbn Bāz'ın âmâ olması (mekfûf el-basar) sebebiyle, tıpkıbasım halindeki mektupta bulunan yazım hataları mazur görülmelidir.'

Elimizdeki malzemeye dayanarak, 1953'teki bu mektubun 1962'de bas1lan bir kitapta yayımlanmasının arka planı kesin bir şekilde belirlenemez. Ancak İbn Bāz, Suudi Arabistan'da köleliğin topyekûn yasaklanmasına karşı çıkan ulemadan biri değil miydi? Her ne kadar 1953'teki mektubunun içeriği, Fahd el-Mārik'in Suudi hükümetini Suudi Arabistan'da yaşayan (ve kanun gereği ülkeye cihat esiri olarak girmemiş olan) tüm köleleri serbest bırakmaya teşvik etme ve aynı zamanda gizli köle ticaretini durdurma amacına karşılık gelse de, görünüşe göre el-Mārik, İbn Bāz'1n, kitabın yazıldığ1 1961/62'deki görüşlerinden artık pek memnun görünmemektedir. Onun, yani el-Mārik'in görüşüne ${ }^{7}$ göre, İslam hukuku bakımından bir kişinin köle alınması sadece bir karşı tedbir olarak meşrudur; örneğin İslam'ın düşmanları ilk defa böyle bir uygulamada bulunduklarında, yani Müslümanları köle olarak esir aldıkları zaman. Bu sava destek olarak ise Kur'an 2:194'e ve 42:40'a işaret etmektedir: 'Her kim haddi aşarak üzerinize saldırırsa siz de tıpkı onların size saldırdığı kadar onlara saldırın' ve 'Kötülüğün cezası ona denk bir kötülüktür.' Her ne kadar bir dipnotta ${ }^{8}$ Suudi hükümetinin köle alım-satımını yasakladığı haberini içtenlikle karşılasa da bu noktada köleliğin esasen yasak olduğu ve bu yüzden de Suudi Arabistan'da kölelerin bulunmaması gerektiği kapsamında net bir açıklamayı halen dile getirmemiştir.

Köleliğin kaldırılması 19. yüzyıldan beri uluslararası siyasetin gündemindedir. ${ }^{9} \mathrm{Bu}$ aslında, İslam ülkeleri hükümetleri üzerine baskıyı ve Avrupa devletlerince yapılan sömürge fetihlerini meşrulaştırmak için bir gündemdir. Dahası, 19. yüzyılda uluslararası kamuoyunun dikkatini bir köle pazarı olarak Hicaz'ın oynadığı role yönelten şey, Afrikalıların Mekke'ye hacca gitmesiyle bağlantılı olan köle ticaretidir. ${ }^{10} 1962$ 'de Fahd el-Mārik'in kitabının yayımladığı sırada, Suudi Arabistan'da ${ }^{11}$ köleliğin sürdürülmesi, Arap hükümetleri ve Suudi Arabistan'daki ideolojik hareketlerin eleştiri konusu haline gelmiştir. Böylece, Fahd el-Mārik gibi kraliyete sadık, fakat aynı zamanda da modernist bir düşünür olan bir Suudi'nin bu durumdan kaygı duyması ve hükümeti

5 Kys. Orient 3/81, s. 390

6 'Abd el-Rahmān b. 'Abdullah Al Şeyh: Meşāhīr 'ulema Necd ve-gayruhum, Beirut 1972, s. 134-144, bkz. oradaki öğrenci listesi s. 137, Nr. 2; Bekrī Şeyh Emīn, s. 604 dipnot 3

7 Lemahāt, s. 62-63

8 A.g.e., s. 62 dipnot 1

9 Bkz. makale "Abd” EI2, I, s. 24-40, özl. s. 36-40 (“Abolition”)

10 W. Ochsenwald: Muslim-European conflict in the Hijaz: the slave trade controversy 1840-1895, Middle Eastern Studies (London), 16/1980/1/115-126. 19. asırda Hicaz'da kölelerin durumu ve "Antisklavereischwindel in Europa” üzerine bkz. C. Snouck Hurgronje: Mekka, cilt II: Aus dem heutigen Leben, Den Haag 1889, s. 11-24

11 Bkz. Cahiers de l'Orient Contemporain (Paris), XXXI/1955, s. 95, ayrica C. W. W. Greenidge: Slavery in the Middle East, Middle Eastern Affairs (New York), 7/1956//435-440 
kölelik ilkesini reddetmeye ikna çabası şaşırtıcı değildir. Kur'an'daki ayetlere dahi, ki burada kölelere iyi davranılması istenmektedir (bkz. 4:36, 16:71), işaret edebilecek olan ulemanın muhtemel direnişine karşı köleliğin varlığ 1 kınanmamıştır. Şurası unutulmamalıdır ki, Fahd al-Mārik'in kitabı, Mısır'ın Ulusal Sözleşmesi'nin (el-Mīsāk el-Vatañ̄) ülkenin 'Arap Sosyalizmi'ne (ki İslam'dan türediği iddia edilir) yönelişini onayladığı aynı yıl içinde sahneye çıkmıştır ve burada Suud ailesinin veliahtları dahi Nasırcılığa karşı sempatilerini ifade etmişlerdir. Bu durumda, Suudi liderliği, Nasırcı (ve Baasçı) polemiklerinin saldırı sahalarını azaltmanın yolunu aramak zorundaydı. Aslında, el-Mārik kitabını yayımladığı sırada, köleliğe ilişkin benzer bir hüküm an meselesi idi: 6 Kasım 1962'deki siyasi beyanında (geleceğin kralı) Başbakan Prens Faysal, bu meyanda köleliğin Suudi Arabistan toprakları üzerinde ilga edilmekte olduğunu ifade etmiştir. ${ }^{12}$

Suudi cephesi tarafından takip edilen tartışma, Birinci Dünya Savaşı'ndan beri İslam'da köleliğin kaldırılmasının asıl eğilim olduğunu (fakat bunun Peygamber'in yaşamı sırasında derhal fark edilmediğini) çoktandır ilan etmiş olan Muhammed Reşit Rıza gibi Selefî̀ yazarların yorumları üzerine bina edilebilirdi; zira ona göre, İslam öncesi dönemin bir mirası olan kölelik, İslam'ın ilk yüzyılından beridir ortadan kalkmıştı. Peygamber ve ilk Dört "Raşid" Halife'nin ardından gelen Müslümanlar ve onların hükümdarları ise şeriata ve onun selefleri tarafindan örnek uygulanışına bağlı kalmışlardı. ${ }^{13} \mathrm{Bu}$, konu üzerine kalem oynatan Müslüman yazarların daha sonraki pek çok beyanının mahiyetini, az ya da çok teşkil etmektedir; liberal modernizm kampına ait yazarlar da tabii ki bu sahaya dahildirler. ${ }^{14}$ Bu bağlam içinde söylenmiş olan her şey, 1962/63 yıllarının Suudi köle özgürleştirme hareketini tesis etmek için elveriş̧li değildir. Örneğin Reşid Rıza'nın da aynı raporda ifade ettiği üzere, babadan oğula geçen monarşinin ilk Emevi halifesi Muaviye tarafından kurulması ölümcül bir adımdı ve şeriattan kopuş bu suretle kendisini göstermişti: Bu, Reşid Rıza'nın (ö. 1935) erken dönem düşünce evresini yansıtan bir tespittir ve Suudi hanedanının 1962'de içinde bulunduğu sıkıntılı durum içinde tabii ki kullanışlı değildir.

Suudi Arabistan'da köleliğin yasaklanması ile bağlantı içinde, 1962/63 yılında hükümet tarafından kölelerin serbest bırakılması ve kendi iktisadi varlıklarını inşa etmelerine maddi açıdan destek olmak üzere bir girişim başlatıldı. Elimizdeki malzemeden İbn Bāz'ın bu gelişmeye karşı nasıl bir tavır takındığına dair kesin bir bilgi ortaya koymak mümkün değildir.

Şayet bugün İbn Bāz’ın, Selefilik içindeki modernizmin son kalıntılarını yok etmek istedikleri izlenimini gayet açıkça sergileyen o eski inatçı Vahhabilerin sözcüsü olduğu söyleniyorsa, bu her şeyden önce o ve bir Iraklının arasında, 1966'da patlak veren bir ihtilafın art etkisidir. Savvāf, 1950'de Irak'ta bir Müslüman teşekkülü olan ve aslında (resmen yasak) Müslüman Kardeşler için bir kamuflaj kuruluşu el-Uhuvve'l-İslamiyye'nin ruhani lideri idi. ${ }^{15} \mathrm{Kās}$ 'm döneminde (1958-

12 Cahiers de l'Orient Contemporain, L/1962, s. 346, 348, a.g.e. ile kys., LI/1963, s. 34, ayrica Oriente Moderno, 42/1962/860; ayrica V. Sheean: Faisal. The King and his Kingdom, Travistock (England) 1975 , s.121

13 el-Menār (Kahire), 13 (1910), s. 742-744, Muneccid/Khūrī (ed.) tarafından yeniden basılmıştır: Fatâwâ 1-imâm Muhammad Rashîd Ridâ, III, Beirut 1970, s. 926-929, özl. bkz. s. 928 Z.-10 ve takip eden sayfa; kys. J. Jomier: Le commentaire coranique du Manâr, Paris 1954, s. 213-233. Reşid Rıza'nın tartışması doğrudan ya da dolaylı yoldan Ahmed Şefik'tendir: L'esclavage au point de vue musulman, Kahire 1891

14 Örn: Muhammed 'Abdullah 'İnān: Mevākif hāsima fī ta'rih el-islâm, 1. bas. 1927, 4. bas. Kairo 1962, ya da İng. tercüme: Decisive Moments in the History of Islam, Lahore 1949, bölüm XIV; Taha Hüseyin: el-fitne el-kubrā, I: 'Uthmān, bas. Kairo 1959 (Maarif), s. 10 ve takip eden syf; 'Abbās Mahmūd el-Akkād: Hakā'ik el-İslâm ve ebātīl khusūmih, 1. bas. Kairo 1957, s. 215-225; Mustafa Shak 'a: İslâm bi'lâ mezāhib, 2. bas. Beirut 1971, s. 62-76

İshak Musa Husaini: The Moslem Brethren, Beirut 1956, s. 84 - Savvāf'ın 1968/69'a kadar olan elyaz- 
63), Savvāf erken yaşlarında komplo faaliyetleri ile meşgul olmuş ,1959'da yurt dışına kaçmış ve nihayet, Mekke'de Arap dili ve şeriat fakültelerinde okutman olarak çalıştığ 1 Suudi Arabistan'a yerleşmiştir. ${ }^{16} 1966$ 'da, Savvāf ve o sırada Medine'deki İslam Üniversitesi'nin rektör yardımcısı olan İbn Bāz, modern gökbilimin ortaya koyduğu bulguların, Kur'an'da bulunan dünya, güneş ve diğer yıldızların kuvvetleri hakkındaki açıklamaların nasıl bir yeniden yorumuna yol açacağı ya da bu açıklamalar içinde gökbilimciler tarafından çok daha sonra keşfedilen gerçeklerin ip uçlarını (işārāt) bulmak sorusu üzerine bir tartışma başlattılar.

Savvāf ihtilafin başlangıç noktasını, 1967'de Beyrut'ta yayımladı̆̆ı el-muslimūn ve'l-ilm el-felek (Müslümanlar ve Gökbilim) adlı kitabının önsözünde anlatmakta ve burada konumunu şöyle teyit etmektedir: Şeyh İbn Bāz, 1966'da Cidde gazetesi el-Bilâd'da (Say1 2111, 20 Ramazan 1885, 12.1.1966) şu bağlığ1 taşıyan bir makale neşretti: eş-şems cāriye ve'l-arz sābite (Güneş Hareket Eder ve Dünya Sabit Durur). Makale Riyad'da çıkan ed-Da've haftalık gazetesinde de aşağı yukarı aynı zamanda ${ }^{17}$ yayımlandı, aynı gazete Savvāf' ın eleştirisini ${ }^{18}$ ve İbn Bāz'ın buna verdiği cevabi ${ }^{19}$ da yayımlamıştır.

İbn Bāz'ın ilk katkısı ve daha sonraki ifadelerinin özü şuydu ki; kendisi, dünyanın güneşin etrafında döndüğü iddiasını (devrān el-arz), Kur'an ve aynı zamanda hadislerin kanıtlarına, yani aleni delillere aykırı olmasından dolayı reddediyordu, uzun lafin kısası; bu tip görüşleri yayanlara karşı savaş açarak, onları kâfir ilan etmişti.

Ancak bu ifadeler, Suudi Arabistan'ın sınırlarının çok ötesinde bir sansasyona neden oldu. Her ne kadar Kral Faysal'ın, İbn Bāz'ın risalesinin içeriğini öğrendiğinde, kalan tüm nüshaların yok edilmesini emrettiği söylendiyse de duyulan kızgınlık artık bu şekilde yeryüzünden silinemezdi. Mesele önü alınmaz bir hal almıştı. Örneğin, Nasırcılığın zirvede olduğu ve o sırada Suudi Arabistan'a karşı Yemen anlaşmazlığı ve diğer bir takım çeşitli sebepler nedeniyle sert polemiklere girmeye zaten hazır olan Mısır basını konuyu derhal gündemine ald1. ${ }^{20}$ Dönemin en önde gelen Nasırcı yazarlarından biri olan Ahmed Bahaeddin, Suudi Arabistan'dan gelen haber üzerine, Nisan 1966'da, el-Musavvar gazetesinde (2166. sayı, s. 15), uzaya yolculuktan alıntılar yaptığ 1 alaycı bir yorum kaleme aldı. Böylece Suudi Arabistan'ın yöneticilerinin stratejisi ve İslam anlayışları alay konusu oldu. O sırada Misır hükümeti Suudi Arabistan'dan daha iyi bir durumda idi: Yıllar önce, el-Ezher'in rektörü Şeyh Mahmūd Şaltūt (ö. 1963), Kur'an'da insanlığın aya gidip gidemeyeceğine ilişkin bir ip ucu olup olmadığına dair uzman görüşü ile çoktan cevap vermişti. Şaltūt'un cevabı, Kur'an'da ne insanlığın böyle bir kapasitesi olduğuna ne de buna karşı söylenecek bir iddiaya dair

malarının listesi Gûrgîs 'Awwād tarafından yayımlanmıştır: Mu'jam al-mu'allifīn al-irâqîyîn, III, Bagdad 1969, s. 240.

16 Uriel Dann: Iraq under Qassem, Jarusalem 1969, s. 112 ve takip eden sayfa, 129, 248

17 Dr. G. R. Puin'in cömert bir şekilde tedarik ettiği ed-Da've'deki bu makalelerin (neredeyse eksiksiz) bir koleksiyonundandır. Görünüşe göre İbn Bāz’ın ilk makalesi el-Bilâd'daki yayımdan birkaç gün önce yayımlanmıştır, ed-Da've Sayı 35, 3.1.1966 ve Sayı 36, 10.1.1966.

18 ad-Da wa Sayı 54-56 (30.5-13.6.1966) Savvāf, üçüncü bölümün sonunda ilan edilen bir devam yazısının yayımından vazgeçmiştir (al-muslimûn wa-'ilm al-falak, s. 11 Z.-6)

19 ad-Da wa Sayı 71 (26.9.1966) - 76 (31.10.1966). Ne yazık ki, Majdhûb tarafından bahsedilen (bkz. aşağ1da dipnot 44), s. 90, İbn Bāz’ın al-adilla al-'aqlîya wa-l-hissîya 'alâ jarayân ash-shams wa-sukûn al-ard wa-imkân as-su ûd ilâ kawâkib ("Güneşin dönüşü ve yeryüzünün sabit duruşu üzerine akli ve hissi deliller ve insanların yıldızlara ulaşabilme olasılığı”) adlı risalesine ulaşamadım.

20 D. Holden ve Richard Johns: The Hause of Saud, London 1981, s. 262 - O yılların Misır-Suud çatışması için bkz. Malcolm Kerr: The Arab Cold War 1958-1967. A Study of Ideology in Politics, 2. bas. London (vs.) 1967, özl. s. 141 ve takip eden sayfa. 
işaret olduğu mahiyetindeydi. Öyle ki, bu bağlamda, insanların şu ya da bu keşfine veya icadına dair Kur'an'ın münferit ayetlerinde gönderme bulma arzusuna karşı öncelikli olarak uyarılmaktayız. ${ }^{21}$

Öte yandan Ahmed Bahaeddin'in yorumu, İbn Bāz'ın ifade ve görüşlerini sergilerken kullandığı üsluba aşina olmadığını açık bir şekilde ortaya çıkarmıştı. Zira İbn Bāz'ın dünyanın yuvarlak olduğu görüşünü de küfür saydığını, hatalı bir şekilde iddia etmişti. İbn Bāz, cevap vermek için bu ayrıntıyı firsat bilerek (ki aslında dünyanın yuvarlak olduğu sorusundan bahsetmemişti dahi) temel pozisyonunu teyit etmiştir. ${ }^{22}$

İbn Bāz'1n, tam da Kral Faysal'ın kendi liderliği altında sosyal-devrimci rejimlere karşı uluslararası bir İslami dayanışma paktı oluşturmak istediği bir sırada, Suudi liderliğine hizmet etmekte başarısız olduğu aşikard. ${ }^{23}$ Zira modern gökbilimin dünya görüşüne karşı sergilediği tavrın hiçbir iyiliği dokunmamıştı. Bu meyanda, Nasırcılar ve Faysal'ın planlarının diğer muhaliflerinin propagandası, İslami dayanışma için Faysal'ın çağrısına cevap veren hükümetlerin 'ithal ideologlar' ve benzerlerine karşı savaşması üzerineydi, zira çeşitli iç ve dış siyasi nedenlerden dolayı (örn. Tunus, İran ve Türkiye), teori ve pratikte İslam'ın (kanun yapma ve eğitimde) oldukça çeşitli bir şekilde anlaşıldığı ortadaydı, haliyle bu pakt inandırıcı bir temelden yoksundu ve İslam'ı kendi kuruluşu için bir araç olarak gören ve onu suiistimal eden Amerikan emperyalizminin bir enstrümanı olmaktan öteye geçemezdi. Böylece Nasırcı karşı propaganda kendi Arap-sosyalist İslam anlayışını üretti ve örneğin Kahire'de 'Arapların Sesi' (savt el-Arab) tarafından yayınlanan 'Allah Düşmanları' adlı radyo programında, muhalif cephede mevcut olan (sekülerizmden Selefiliğin kaba çeşitlerine kadar) farklı İslam yorumlarının uyumsuzluğunu aydınlatmayı denedi. ${ }^{24}$

Bu durumda, Suudi liderliği için İbn Bāz'in hem yerel teknokratik ve yönetici seçkinler hem de çok sayıda Suudi öğrenci ve İslam ya da İslam dışı yabancı ülkeler üzerine ortaya koyduğu görüşlerin olumsuz etkisini bir nebze de olsa etkisiz hale getirmek gerekliydi. Böylece, liberal modernizmden etkilenmiş Selefî yönelimli entelektüel grupların bir üyesi olan Savvāf'ın, özellikle de 1950'lerden beridir Suudi Arabistan'a sığınmış olan gazetecilerin, öğretmenlerin, siyasi müşavirlerin ya da 'özel bir propagandaya hizmet eden misafirler'in vakti gelip çattt. ${ }^{25}$ Savvāf, Mekke'de, yerel-bölgesel otorite tarafından (idārat et-tảlìm) eğitim amaciyla düzenlenen bir dizi kültürel faaliyette (mevsim sekāfì), Kur'an ifadeleri ve modern gökbilimin dünya görüşünün benzeştiği görüşünü kamuya duyurmak için bir ders verme fırsatı yakaladı. İlkin, (yaklaşık yirmi yıldır gayet iyi tanıdığı) İbn Bāz'a, önce eleştirel bir mektup gönderdiğinden ve fakat ondan geri adım atmaya dair hiç niyeti olmadığını gösteren bir cevap aldığından bahseder. Kendi ifadesine göre, Mekke ve Cidde'den pek çok eğitimli insanın katıldığı olumlu bir yankı görmüştür. Bu da onu kendi görüşlerinin, yani İbn Bāz’a gönderdiği eleştiri mektubunun ve verdiği dersin tam metnini ed-Da've

21 Mahmûd Shaltût: al-fatâwâ, 6. bas. Beirut ve Kairo 1972, s. 394

22 ad-Da'wa Say1 53 (23.5.1966)

23 Tilman Nagel: König Faisal von Saudi-Arabien und die "islamische Solidarität", Orient 1/76, s. 52-71; W.A. Beling (ed.): King Faisal and the Modernisation of Saudi Arabia, London 1980, özl. s. 173 ve takip eden sayfa; N.O. Madani: The Islamic Content of the Foreign Poliy of Saudi Arabia. King Faisal's Call for Islamic Solidarity 1965-1975, Ph. D. Ann Arbor, Mich. 1977; Z. Önder: Saudi Arabien, Stuttgart 1980, s. $189-227$

24 Mısır ile ('Şeytan Dostları' adında bir program yayımlamış olan) (Kuzey) Yemen Cumhuriyeti arasındaki yayıncılık savaşına iyi bir bakış bir yanda ve diğer yanda da Suudi Arabistan olmak üzere BBC'nin Monitoring Service'i (İngilizce) bir özet sunmaktadır: Summary of World Broadcasts, Part IV: The Arab World (vs.). 1967 Haziran Savaşı’nın ardından 'Allah Düşmanları' adlı program kesilmiştir (F. Halliday: Arabia without Sultans, Harmondsworth 1974, s. 78 dipnot 28). 
gazetesine yayımlanmak üzere göndermeye cesaretlendirmiştir ${ }^{26}$ (ya da resmi makamlarca cesaretlendirilmiştir?) Ardından, bunların tümünü, yukarıda bahsi geçen 1967 tarihli kitapta, kısmen daha uzun bir şekilde, Beyrut'ta neşretmiştir. Kitabın pazarlanması ise (ki içinde, İbn Baz'ın bir yıl önce küfür olarak nitelendirdiği görüşler yansıtılmaktaydı) Cidde'deki ed-Dār es-Su 'üdīyya li'n-Neşr şirketi tarafindan üstlenilmiştir.

Kitabın başlangıcındaki teşekkür bölümüne bakılırsa, bu sürecin siyasi çerçevesi geniş bir manada görülebilir: En başta Suudi Eğitim Bakanı (ve aynı zamanda Vahhabiliğin kurucusunun aile temsilcilerinden biri olan $)^{27}$ Hasan ibn Abdullah Āl el-Şeyh'ten bir mektup gelir. Burada Savvāf, kültür festivaline faal katılımından dolayı kendisine teşekkürünü sunar, ardından Mekke bölgesinin eğitim müdürü Mustafa el-Attār'ın mektubu vardır. Savvāf tarafından verilen her iki dersin içeriği ise dahil edilmemiştir.

Kitabın tarihi üzerine giriş bölümündeki sözlerin ardından (s. 9-12) Savvāf, Pakistanlı ilahiyatçı ve siyasetçi Ebū'l-A 'lâ el-Mevdūdī'nin (ö. 1979), Şeyh İbn Bāz'ın yorumlarını ve Savvāf'ın yazdığı (henüz yayımlanmamış olan) eleştiriyi okuduktan sonra, hicri 1385 'te (Mart-Nisan 1966) kendisine vermiş olduğu mektubun metnini takip etmektedir. Bu mektupta, Suudi Arabistan'da oldukça yüksek bir saygı gören Mevdūdī açıkça Savvāf' ın yanında saf tutmuştur. ${ }^{28}$ Mevdūdī’nin Savvāf'a verdiği destek, sadece Suudi Arabistan'da gördüğü yüksek itibardan dolayı önemli değil, fakat aynı zamanda İslami modernizme karşı takındığı özel tutumdan dolayı da önemliydi: Bir yandan, İslam'ın akıl ve bilim üzerine temellendiğini, ömrünün ve geleceğinin ise tam da (modernizmin on dokuzuncu yüzyıldan beridir öne sürdüğ̈̈ gibi) ${ }^{29}$ bilim ve teknolojinin sonuçları ile ilkeli bir mutabakat içinde oluşundan kaynaklandığını tekrar tekrar vurguluyor, diğer yandan da İslami modernizmin kurucu babalarından biri olan Muhammed Abduh'u (ö. 1905) eleştirme cüretini gösteriyordu: “(...) Batı medeniyeti İslam’ın erdem ve 'kusurları’nın yargıcı kesilmiştirvaziyet bunun aksi değildir... Mısır'da, Şeyh Muhammed Abduh ise benzer çizgide bir uzlaşma benimsemiş ve kendisinin takipçisi olan Arapça konuşan dünyada Batılılaşma yanlıları için kapıyı aralamıştır." ${ }^{30}$ Oysa nihayetinde Mevdūdī ve benzeri İslamcılar, İbn Bāz ve Savvāf'1n, Kur'an'ın ifadeleri ve modern (Batı) biliminin bulgularına ilişkin farklı görüşlerini, en azında sathi dahi olsa, birbirine yaklaştırma ihtimali üzerinde çalışıyorlard1.

Mevdūdī’nin mektubunun ardından Savvāf, Müslüman Kardeşler eğilimli, Suriyeli bir ilahiyatçı olan ve o sırada Mekke' de yaşayan Şeyh Ali et-Tantāvī'ninn ${ }^{31}$ bir mektubunu ${ }^{32}$ yayımlar. Bu

\footnotetext{
26 al-muslimûn wa-'ilm al-falak, s.111-113

27 Kys. Orient $3 / 81$, s. 387 dipnot 47

28 al-muslimûn wa-'ilm al-falak, s. 13-15

29 E. Lerman: Mawdudi's Concept of Islam, Middle Eastern Studies (London), 17/1981/4/492-509, bkz. özl. s. $497-498$

30 A.g.e., s. 496, (alınt1) Correspondance between Maududi and Maryam Jameelah, Lahore 1969, bkz. özl. s. $497-498$

31 Tantāvī (d. 1909), Muhibb ed-Dīn el-Hatīb'in bir yeğeni (bkz. Orient 3/81, s. 387-388), bir yazar olarak ortaya çıkmıştır. Federal Alman Cumhuriyeti’nde yaşayan Suriyeli Müslüman Kardeşler'in lideri 'İsām el-'Attār'ın kayınpederidir. Tantāvī'nin kızı olan karısı Aachen'de, Mart 1981'de bir suikaste kurban gitmiştir. Uluslararası basındaki yankılara örnek olarak bkz. T.F. Brady: Saudis Debating Science 'Heresy', New York Times, 5. Haziran 1966, s. 12, Suudi Bilişim eski Bakanı Cemil Huceylan'ın ifadesinden alıntı: 'Şeyh İbn Bāz, kendi görüşlerine sahip dini bir liderdir ve hükümeti temsil etmez. Hatta, hakim görüşten önemli bir hizbi de temsil etmemektedir.' Bu makalenin bir nüshasını elde eden Bayan G. Max’a teşekkür ederim.
} 
mektubunda Tantāvī, İbn Bāz’a verdiği cevabı kitabında basması planı için Savvāf’ı teşvik etmektedir, 'çünkü İslam düşmanları (İbn Bāz'a ait) bu makale ile firsat yakalamış ve üzerine yorumlar yazmışlardır, Avrupa ve Amerikan gazeteleri ise bunları (alaya alan) yazılarla doludur.' İbn Bāz'ın önemli bir alim olmasına karşın, kendisi hiçbir surette hatadan yoksun değildi. Görüşü bir kısım ulemaca paylaşılmaktaydı ${ }^{33}$ fakat Tantāvī'nin sorduğu, 'İslam Dünyası Birliği'nin önde gelen üyelerine göre, İslam dünyasının tüm kesimlerindeki Müslüman ulemanın çoğunluğu aynı fikirde değildi. Bu arada Tantāvī, ne Kur'an'da ne de hadiste dünyanın güneşin etrafında döndüğü ya da yörüngesine dair açık bir delil olarak kabul edilebilecek kesin bir ifadenin (nass-ı kat $\widehat{\imath}$ ) olduğu kanaatindeydi. Bu görüş, onun - tıpkı Savvāf gibi - belirli Kur'an ayetlerinde modern bilimin keşif ve icatlarına dair işaretler ve imaların olabileceğini mümkün görmesi dolayısıyla, Şaltūt'un yukarıda bahsi geçen hükmünden farklılık göstermektedir. İbn Bāz ve dünyanın güneş etrafında döndügünü kabul etmeyen diğerlerinin kanıt olarak Kur'an'dan alıntıladıkları ayetler, örneğin 16:15 ve 31:10 ("Sizi sallayıp çalkalar diye yeryüzünde sabit ve muhkem dağlar ... koydu"), aynı zamanda dünyanın dönüşüne ilişkin ip uçları (işāāât) verdikleri şeklinde de okunabilirlerdi.

İbn Bāz ve Savvāf arasındaki ihtilaf, İslami modernizmin temel bir sorununa değinmektedir. Bunun varsaydığına göre, doğru anlaşılan İslam ile modern bilimin bulguları arasında bir ihtilaf olamaz. ${ }^{34}$ Modernist Kur'an müfessirlerinin (ki bunlar çoğu zaman yoğun bir ilahiyat öğrenimi olmayan doktorlar, mühendisler vb. kişilerdir) Kur'an'da modern (Batılı) bilimin keşiflerinin kanıtlarını aradıkları yadsınamaz. Haliyle bu sadece klasik tefsirlerin yetkinliğini baltalamakla kalmaz, aynı zamanda dayanaksız görüşler ve çılgınca kıyaslara kapı aralamaktadır. Zaten Muhammed Abduh, Kur'an'ın ifadelerinde bakteriyoloji keşiflerine dair cin üzerine göndermeler varsayımının çekiciliğine direnememiştir. ${ }^{35}$ Onun öğrenci çevresi, (1910-18'de neşredilen) on ciltlik 'Yirminci Yüzyıl Ansiklopedisi' ile Muhammed Ferid Vecdī (ö. 1954) ve el-Menār'da Kur'an ve gökbilim üzerine yayımlanan bir makalesi ile Muhammed Tevfik Sıdkī gibi bu yönde önemli ilerleme kaydeden birkaç yazarın doğumuna vesile olmuştur. ${ }^{36}$ Öte yandan bu çabalar, Şii bölgesinde de derhal benzer bir yankı bulmuştur: 1910 gibi erken bir zamanda, Iraklı ilahiyatçı Hibat ed-Dīn eş-Şehristānī (ö. 1967) Bağdat'ta el-Hay'a ve'l-İslam ('Gökbilim ve İslam', 3. bas., Necef 1965) adlı bir kitap yayımladi; Abduh'un etrafındaki halkanın bazı yazarlarıyla aynı şekilde, Kur'an'da gökbilimin o zamanki en son bulgularını tasdik etmiş ya da öngörmüştü - ancak şu farkla ki, On İki İmamcı bir Şii olarak onun için bazı imamların (özellikle de Ali ve Cafer es-Sādık'ın) belirli ifadeleri yüksek bir delil değerine sahipti ve kendisi için uygun görünen her durumda alıntılanmaktaydı.

Tabii ki, daha sonraki birçok yazarın yorumu, kısa sürede Abduh ekolünün mirasının bazı vasileri için oldukça ileriye gitmiştir: Tantāvī Cevherī'nin (ö. 1940), "tıpkı doğa tarihi üzerine modası geçmiş bir kitap gibi, sık sık Kur'an'dan ayet alıntıları ile kesintiye uğrar ve bu alıntılar, kitabın yazar tarafından üzerine yazacak olduğu doğa tarihinden seçilmiş mesele ile öyle ve ya böyle

33 Daha fazla ayrıntı vermeksizin, Tantāvī, sadece Suriyeli ilâhiyatçı, içinde İbn Bāz’ın pozisyonunun desteklendiği, Muhammed el-Hāmid'in (ö. 1969) bir kitabını zikretmektedir. Bu muhtemelen Rudūd ve-ebātīl'dir, bir makaleler ve kısa yazılar koleksiyonudur, bkz. Hamid'e ek ve genel Abd al-Hamīd Tahmāz: al-'allâma al-mujâhid ash-shaikh Muhammad al-Hâmid, Damaskus ve Beirut 1971 (Dar al-Qalam), burada özl. s. 110 ve alıntı s. 90 ve takip eden sayfa.

34 C.C. Adams: Islam and Modernism in Egypt, London 1933, özl. s. 127-143

35 A.g.e., s. 138

36 Brockelmann, GAL S III, s. 323-325; tüm sorunsal sahası için bkz. J.J.G. Jansen: The Interpretation of the Koran in Modern Egypt, Leiden 1974 (yen. bas. 1980), Kap. III: Koran Interpretation and Natural History (s.35-54)

37 Bunun için bkz. EI2, Fask. 5-6 (Leiden 1982), s.262-263 
bir şekilde ilişkilendirilir"38 diyen Kur'an tefsiri, Muhammed Reşid Rıza tarafından dolaylı, fakat sert bir saldırıya uğramıştır. Bu ve diğer bazı Selefî temsilcilerin eleştirileri, Tantāvī Cevherī’ye ait Kur'an tefsirinin Suudi Arabistan'da yasaklanmasına katkı sağlamış olabilir. ${ }^{39}$

İbn Bāz eleştirisinde Savvāf, akıl yürütmesinin Tantāvī Cevherī gibi yazarlarınkine çok yakın olmamasına özen göstermek zorunda kaldı; evet, Kur' an tefsiri için, Vahhabi rakiplerince itiraz edilmesi mümkün olmayan bir kaynak arama kaygısı duymuş olmalıdır. Aradığını da öğrencisi Muhammed Behçet el-Eserī'ye 1921 y1lında, Mā delle 'alaih el-kur'ān mim-mā ya 'zud el-hay 'a el-cedìde ("Kur'an' da Modern Gökbilimsel Dünya Görüşünü Tasdik Eden İşaretler”) adlı kısa bir makale yazdıran Iraklı Sünni ilahiyatçı Mahmūd Şukrī el-Ālūsī’de (ö. 1924) bulmuştur. ${ }^{40}$

Mahmūd Şukrī el-Ālūsī Selefiliğin önemli bir savunucusu olarak Suudi Arabistan'da büyük sayg1 görmektedir. ${ }^{41}$ Fakat 1921 tarihli risalesi ancak ölümünden sonra neşredilmiştir. ${ }^{42}$ Ālūs̄̄'ye yazarak Savvāf, ${ }^{43}$ potansiyel eleştirmenlerini, Selefî dünyası içinde saygın bir yer tutan ve inançsızlıkla (kufr) suçlanması mümkün olmayan bir yazarla uğraşmaya zorladı. Savvāf ve müttefikleri bu yüzden en ön sırada gitmek zorundaydılar: Amaçları, İbn Bāz'ın, modernistlerin Kur'an ifadelerini çağdaş gökbilimsel dünya görüşü ile uyumlandırma girişimlerine karşı onları inançsızlıkla suçlamasını çürütmekti. O ve kendi kategorisindekiler için, büsbütün Batılı bilim ve teknoloji ile karşı karşıya kalan yeni nesli, Müslüman dünya içinde İslam'ın ebedi geçerliliğine ve meşruluğuna ikna etmek ancak bundan sonra mümkün olabilecekti. Bu sırada Suudi hükümetinin yerel bir teknik istihbarat servisi kurmak üzere çoktan açıkça karar almış olması, zorunlu olarak Savvāf'ın başarısına bağlıdır.

Savvāf ve müttefiklerinin İbn Bāz üzerine verdikleri cevaplar belirli bir etki bırakmış gibi görünmektedir. Gerçekten de İbn Bāz, ihtilaftan yıllar sonra görüşü sorulduğunda, prensipte eski görüşünde 1srar etse de, artık farklı görüşlerin aleyhinde konuşmaktan ve hatta inançsızlık iddiasını kanıtlama çabasından kaçınmaktadır. ${ }^{44} \mathrm{Bu}$ bağlamda - İslam düşüncesinde uzun ve tartışmalı bir tarihe sahip olan bir kavrama işaret eder, fakat bu inançsızlık ya da küfür değerlendirmesinden çok daha 1lımlıdır - 'içtihatlarında hata yapmış' (muctehidūn muhti 'ün) ${ }^{45}$ alimlerden bahseder. $\mathrm{O}$ dönemden itibaren benzeri sorular üzerine kamuya yaptığı açıklamalar öylesine formüle edilmiştir ki, Savvāf dahi atık onunla hemfikir olabilirdi. Örneğin İbn Bāz, 31.2.1982'de Demmam'daki Kral Faysal Üniversitesi'nde öğrencilere verdiği bir konferansta, modern bilimsel teorinin Kur'an 1şığında gayet iyi yorumlanabileceğini, fakat bunun tersinin (yani: modern bilimden getirilen kanıtlarla Kur'an'ın doğruluğunu ve ebedi geçerliliğini kanıtlamanın) yanlış olduğunu söylemiştir. ${ }^{46}$ Görünüşe göre burada İbn Bāz, modernizmin belli başlı tezahürleri üzerine Mevdūdī’nin yaptığı

38 Jensen: The Interpretation, s. 32

39 A.g.e., s. 32 ve 45

40 Muhammad Bahjat al-Atharî: A'lâm al-'Irâq, Kairo 1345 h (1926-27), s. 143 ve takip eden sayfa

41 Bkz. Orient 3/81, s. 386, 35. dipnot ile birlikte; Hal tercümesi, Reşid Rıza’nın yanında (Mash. S. 286287) Mashâhîr ulama Najd'dedir (bkz. dipnot 6, kys. Orient 3/81, s. 387)

42 'Avvād'a göre (bkz. dipnot 15), III, s. 275, ilk 1960'da Şam'da

43 Defaatle Abdurrezzak Nevfel'in kitabına dayanmaktadır: Allâh wa-l-'ilm al-hadith, Kairo 1957

44 Bu, Medine'deki İslam Üniversitesi’nde doçent olan Muhammed el-Mecdūb’un, İbn Baz’la bir konuşmasının ardından edindiği izlenimdir, bkz. Mecdūb: 'Ulama' wa-mufakkirûn 'araftuhum, Beirut 1977, s. 87-88. Mecdūb, kitabı Mushkilât al-jîl dau' al-islâm'dan bahseder ve burada İbn Bāz ve muhaliflerinin tutumunu sergilemektedir. Bu kitap (Dr. Klaus Kreiser'den, Münih, ed. Beyrut 1970, edindiğim bilgiye göre) erişimim dahilinde değildir.

45 Mecdūb: 'Ulama', s. 87. - Terim için bkz. Makale "Khata'” EI2, İngl. ed., IV, s. 1100-1102

46 Arab News (Cidde), 1.4.1982, s.2 
ayrımdan doğrudan etkilenmiştir. ${ }^{47}$

Bu makalenin çerçevesi içinde, Savvāf' in İbn Bāz'la olan tartışmasındaki pozisyonunun bir açıklaması gerekli değildir. Ancak vurguladığı iki yönden burada bahsedilebilir: Savvāf, doğa bilimi çalışmalarının yaratıcı tanrıya inançlarını pekiştirdiğini vurgulayan ve orta çağ Müslümanlarının gökbilim sahasındaki sıradışı başarılarını aktaran Batılı gökbilimcilerin ya da gökbilim üzerine popüler bilim kitaplarının yazarlarının görüşlerine atıfta bulunmayı sever. İslam medeniyetinin ihtişamından duydukları gururu perçinlemek için genç Müslüman nesillerin bilmesi gereken başarılardır bunlar. Onların anısı ise, modern bilim çalışmak için bir teşvik olarak hizmet görecektir.

Savvāf, 1966'da İbn Bāz'la karşılaştığında, Suudi Arabistan çoktan modern bir üniversite ve bir teknik kolej inşasına başlamışt ${ }^{48}$ ve sayıları gitgide artan genç Suudiler eğitim için yurt dışına gönderilmekteydi. Bu sırada Suudi hükümeti için, (ister nükleer fizik ya da oryantalist çalışmalar sahasında) Batı bilim-teknolojisi, (ister Suudi Arabistan'da ya da ABD'de) endüstriyel toplumun yaşam tarzı ve İslam karşııı ideolojilerle karşılaşan öğrencilerin İslam'a olan bağlılıklarını korumaları zorunluydu ve bu da uygun yönlendirmelerle teşvik edilmeliydi.

1970'lerin başlarında ABD Oregon'da yaşayan Suudi öğrenciler arasında, İslam ve Hristiyanlığa karşı sergilenen tutum üzerine yapılan bir tezde varılan sonuca göre, bu öğrencilerin çoğunluğu, kendilerine yöneltilen anket ve röportajlarda, ABD'deki ikametleri sırasında, her ne kadar gündelik yaşamın İslami normlarına her zaman sadık kalamasalar da, İslam'a olan bağlılıklarının zayıflamak bir yana, daha da güçlendiğini ifade etmiştir. ${ }^{49}$ Öte yandan sadece yüzde altılık bir dilim inançlarını kaybettiklerini ya da kaybetmek üzere olduklarını belirtmiştir. Tabii ki, görünüşe göre sonuncusu, Birleşik Devletler'e gelmeden önce, kendi çevrelerinde İslam anlayışından zaten sapmıştır. Geriye kalan içinse, sorular cevapsız kalmaktadır: Sonuçlar, Batı'da okuyan tüm Suudi öğrencileri ne derece temsil etmektedir ve bu konulara cevap verenlerden ne derece bir samimiyet beklenebilir? ${ }^{50}$

Suudi Arabistan'daki sorumlu grupların, öğrencilerin dinen yeniden inşası ve donanımlarının iyileştirilmesi bakımından tasavvurları üzerine Mahmūd es-Savvāf çarpıcı bir örnek sunmaktadır. 1960'ların başındaki bir makalede ${ }^{51}$, Taif' deki bir kitap dükkanında, 1961 yazında düzenlediği bir toplantıdan bahsetmektedir: İyi giyimli, zeki görünümlü genç bir adam, kitapçıya Varoluşçuluk (vucūdiyye) üzerine makaleler içeren bir kitap sorar, fakat istediği kitabın olmadığı ve hatta konu üzerine başka herhangi bir kitabın da olmadığ Arap sosyalizmi üzerine kitaplar sorar. Nihayet Savvāf kendisine hâkim olamayarak genç adamla sohbete koyulur; genç adam Riyad'dan gelmektedir, Beyrut Amerikan Üniversitesi'nde okumuştur ve toplantıya da vucūdiyye hakkında bilgi edinmek için katılmıştır. Savvāf, genç adama, bu üniversitenin, Müslüman gençliğini yozlaştırmak ve onları ateizme (ilhād) çekmek için kurulmuş, emperyalizmin ve Hristiyan misyonunun (cāmi a tebşîrìye isti 'mārìye) hizmetinde bir üniversite

47 Yuk. bkz.

48 Bkz. bölüm "Higher Education", A. Dawson, R. Dunipace et al. (ed.): The Kingdom Saudi Arabia, London 1979, s.200-212; kys. A. Alkazaz: Der Aufbau moderner Forschungsintitutionen in SaudiArabien, Dokumentationsdienst Moderner Orient. Mitteilungen (Hamburg), 4/1975/1/38-53

49 R.M. Kershaw: Attitudes Towards Religion of Saudi Students in the United States, Ph. D.. Univ. of Southern California, 1973, bkz. özl. s.70, 89-90 ve 166-173

50 İkinci soru için bkz., s. 161-165

51 "Die Geschichte von dem jungen Mann, der Atheist wurde und seinen Glauben wiederfand", ilk defa en-Nedve (Mekke) gazetesinde yayımlanmıştır, Lâ ishtirâkîya fî l-islâm kitapçığında yeniden basılmıştır, Kairo, 3. ed. 1978 (Dâr al-Ansâr), s. 21-28 
olduğunu açıklar. Öte yandan, Beyrut Amerikan Üniversitesi bu hedefe ulaşmakta maalesef başarı1 dahi olmuştur. Böylece, Genç Suudi aslında ateist olduğunu, fakat geri dönmeye başladığını itiraf eder. Konuşmanın ilerleyen bir merhalesinde Savvāf, İslam ile sosyalizmin ve İslam ile (seküler) milliyetçiliğin birbirleri ile bağdaşmaz oldukları hususunda bu öğrencinin gözlerini açtığını ve ona okuması için gerçekten faydası dokunacak İslami kitaplar tavsiye ettiğini anlamaktadır. (Fakat sonradan anlaşıldığı üzere Taif’ deki kitap dükkanında da değillerdir.)

Savvāf bir zeyl ile sonuca varır: Takip eden sene mevzu bahis kitapçıya bir ziyareti sırasında kitapçı, neşe içinde, genç adamın kendisine - yani Savvāf'a - selam gönderdiğini, bu yolla İslam'a koşarcasına geri döndügünü ve İslami metinleri tekrar tekrar yoğun bir şekilde okumaya koyulduğunu bildirmesini rica ettiğini söyledi. Bu zaferden (ki bunun kendisinin olduğuna inaniyordu) memnun olan Savvāf, şayet bu görev için tayin edilen kişiler doğru bir şekilde işe koyulurlarsa, tıpkı yukarıdaki vakada olduğu gibi, yoldan çıkan gençliğin İslam’a geri kazandırılmasında genel manada başarılı olunabileceği sonucunu çıkarmıştır.

Bugün, (uydurma ya da gerçek olsun) Savvāf ve Taif'deki öğrenci arasındaki konuşmanın üzerinden yirmi yıl sonra, Suudi Arabistan hükümeti yabancı ülkelere burs kazananları en azından eğitim kurslarına (örneğin, Kur'an, hadis ve halifeler tarihi bilgilerini tazelemek için derslere) tabi tutmaya başlamıştır. İç İşleri Bakanı Prens Nāyif, böyle bir eğitim kursunun ilkinde (ki bu yılda altı kez düzenlenmektedir) yetmiş sekiz katılımcıya, Riyad'daki İmam Muhammed ibn Suud Üniversitesi'nde, 1982 yılındaki konuşmasında açıkça şöyle söylemiştir: ${ }^{2}$ 'Öğrenciler yurt dışında yıkıcı ideolojilerle karşılaşacaklardır, onlara direnebilmeleri için gerçek ve tehlikeli yüzleri hakkında aydınlatılmaları gereklidir. Ülke dışında, gençlerin ılımlı ve meraklı zihinlerine, kendi inançlarına, kendi halklarına, kendi siyasi, toplumsal ve iktisadi şartlarına aykırı olan şüphecilik halinin tohumlarını eken çevreler var, sathi, yanıltıcı vs. şeyler öğreterek onları oyalamak istiyorlar, hiç şüphesiz bunlar Araplar ve İslam'ın faydasına değildir.' Suudi Arabistan yabancı uzmanlara bağımlı kalmak istemediği için, hâlâ yurt dışına öğrenci göndermek zorundadır, fakat, pek çok öğrenci için güvenli olmayan bu gidişatın üstesinden yakın zamanda gelinecektir; çünkü kendi üniversite sistemleri, en yüksek bilim-teknik eğitim programları için dahi yurt dışında okumayı artık gereksiz hale getirecektir. Ardından, tıpkı şimdi kısmen olduğu gibi, özel eğitim için yurt dışına genellikle daha yaşlı ve daha olgun öğrenciler gönderilecektir.

Üniversite öğreniminin yurtiçinde tedricen yeniden tesis edilmesi ve bu yüzden de yurt d1şında okumanın getirdiği bazı arzu edilmeyen sonuçlar ve bunların yan etkileriyle karşılaşma düşüncesi, birkaç nedenden dolayı, diğer pek çok üçüncü dünya ülkesi hükümetince de göz önünde bulundurulmuş ve kısmen uygulanmıştır, ayrıca bu sanayileşmiş ülkelerdeki eğitim ve kalkınma politikalarıyla da tam olarak örtüşmektedir. Suudi İçişleri Bakanı'nın, istenmeyen ideolojik nüfuzlara ilişkin konuşmasında ifade ettiği kaygıya gelince, aşağıda söylenenler kesinlikle göz önünde bulundurulmalıdır: Bu ülkelerin ulusal üniversitelerinde istihdam edilen ya da edilecek olan yerli üniversite öğretmenlerinin ilk nesilleri, büyük oranda İslami olmayan (kapitalist ya da sosyalist) yabancı ülkelerde eğitim görmüşlerdi. Bu özellikle tıp ve bilim-teknik sahası için doğrudur. Suudi Arabistan durumunda ise, bunların neredeyse tamamı ABD ve Batı Avrupa'da eğitim görmüş ve şimdi yavaş yavaş Batı ve diğer (Mısır, Pakistan, vb.) İslam ülkelerinde öğretmen olmaya aday uzmanlardır. Zahran'daki Petrol ve Mineral Üniversitesi'nden yapılan bir araştırmaya göre meslek olarak üniversite profesörlügüü, Suudi öğrencilerinin mesleki arzularının saygınlık ölçeğinde birinci

52 18.3.1982'den Saudi Gazette ve Arab News'e göre (her ikisi de Cidde'dedir), s.1 ve takip eden sayfa, özl. s.3, kys. Bilişim Bakanı'nın konuşması, Dr. Muhammad Abduh Yamânî, böyle bir kursun katılımc1larının huzurunda, 9.5.1982'den Arab News ve Saudi Gazette'ye göre, s.2 özl. 3 
basamağı tutmaktadır - bu doktorluğun, hatta memurluğun ve bankacılığın dahi önündedir. ${ }^{53}$

$\mathrm{Bu}$ yeni nesil üniversite öğretmenlerinin en azından İslam ve modern bilim arasındaki ilişki bakımından (bunun inanç temelli olup olmadığı ise cevaplanmamış bir sorudur) az ya da çok liberal modernizme karşılık gelen bir tutum sergileyecekleri varsayılabilir. Eski Vahhabiliğin temsilcileri ile gerilim ise, geçici süreliğine dahi olsa da büsbütün kaçınılmazdır. Bu, belki çok daha fazla bir şekilde, özellikle beşerî bilimlerin belirli sahaları için geçerlidir.

Halihazırda ve gelecekteki gelişimin bu ikinci veçhesi içinse, Şeyh İbn Bāz'1 içeren bir tartışma, öğretici bir örnek sunmaktadır: Ed-Da've (Riyad) gazetesinin hicri 24.5.1387 (30.8.1967) tarihli sayısında, Mekkeli gazeteci, yayımcı ve yazar Salih Muhammed Cemal ${ }^{54}$, Hac ve Dini Vakıflar Bakanlığı'nın Eğitim Bakanlığı ile işbirliği içinde, Mekke ve Medine bölgesindeki (eski) İslam eserlerini (el-āsār el-islāmīyye) restore etmesini, bu alanlar ve binalar üzerine yapılan bilimsel çalışmaları teşvik etmesini, mevzubahis mekanları gösteren şehir ve bölgesel haritaların yapımını ve hatta yerel duyuru panoları asılmasını önerir. ${ }^{55}$ Ayrıca, Mekke yakınlarındaki Hira Dağı Mağaras ${ }^{56}$ gibi ulaşılması zor bölgelere erişim, yollar, elektrikli asansörler vb. yapısal önlemlerle kolaylaştırılmalıdır. Bu yerler ve eski dönem anıtlar üzerine bilgilerse ders kitaplarına eklenmeli, ziyaretçiler için de öğrenciler rehber olarak istihdam edilmelidir. Cemal, bu bağlamda, bu tür yerleri ziyaret etmenin büyük derecede popüler bir eğitim değeri olduğundan ve bunun diğer ülkelerde uzun zamandan beri tanındığından bahsetmektedir. Öte yandan Peygamber'in yaşamıyla ve bundan dolayı da her Müslümanın tarihsel bilinciyle yakından bağlantılı olan Mekke ve Medine'nin kötü şartlar altında ve bulunmalarının zor olduğunu dile getirmektedir. Cemal, Shakespeare'in evi ya da Beethoven'in doğum yeri gibi ziyaretçiler için ilgi çekici yerleri olumlu birer örnek olarak sunmakta ve restorasyonlar sayesinde ortaya çıkan Firavunların kültürünün muhteşemliği ve Sfenks'teki 1şık oyunlarıyla Mısır'ın çabalarından övgüyle bahsetmektedir, zira bunlar hem kendi halkını etkilemekte hem de yabancı turistleri bilinçlendirmektedir.

Şeyh İbn Bāz, bu önerilere ed-Da 've' de (sayı 119, 18.9.1967, s. 2) yayımlanan bir makale ile kesin bir dille karşı çıkmıştır: Eğer biri eski İslami alanları ve anıtları restore edecek olursa, onları daha tanınır ve ulaşılabilir hale getirmiş olacak, yayınları vb. şeyler aracılığı ile onları methedecektir, o zaman pek çok ziyaretçi bunları bir ibadet ( ta 'abbud) olarak görür ve bunlarla Allah'a yakınlaşmaya çalışır (takarrub); böylesi yerleri aramaya koyulmak, gerçek İslam (yani Vahhabilik) tarafından kesin bir şekilde reddedilen inanç yaşamı şekillerine götürür. ${ }^{57}$ Cemal'in önerileri, eski İslami alanların tarihinin tüm okulların müfredatına dahil edilmesi teklifi hariç, şeriata da aykırıdır. Öte yandan, bu yolla Hz. Muhammed'in yaşamı ve eseri öğrencilere öğretilecekse o zaman bir itiraz yoktur. ${ }^{58}$

Salih Muhammed Cemal, ed-Da ve'nin 126. sayısında (6.11.1967) bu ifadelere cevap vermiştir. Cemal, İbn Bāz tarafından yanlış anlaşıldığını hissettiği bazı ayrıntıları düzeltmesinin ardından, ya da yasak bid 'atların girişine izin vermesi korkusuyla çekindiği yerlerde, Endülüs'teki

\footnotetext{
53 Arab News, 13.3.1982, s.3

54 Bakrî Shaikh Amîn, s. 120 ve 'Abd as-Salâm Tâhir as-Sâsî: al-mausû'a al-adabîya; dâ'irat ma ârif liabraz udabâ' el-Mamlaka al-'Arabîya as-Sa' ûdîya, II, Mekka 1394h/1974, s.249-56

55 Cemal'in kaleme aldığı bu ilk makaleye ulaşamadım. İçerik İbn Bāz'ın sorusu ve Cemal'in cevabından oluşmaktadır. Buna mukabil, Sayın Dr. G.R. Puin (Saarbücken) sayesinde alıntılar elimdedir.

56 Bkz. EI2, III, s. 462

57 Bkz. Orient 3/81, s. 380 ve takip eden sayfa

58 Mısır'da Firavunculuk ve Arap milliyetçiliği çatışması için bkz. I. Gershoni: The Emergence of PanArabism in Egypt, Tel-Aviv 1981, birçok yerde atıf vardır.
} 
Arap-İslam eserleri ve benzerlerini ziyaret eden ve böylelikle Orta Çağ Arap-İslam medeniyetinin ihtişamı ve kültürel başarıları üzerine izlenim sahibi olan sayısız Müslüman ve gayrimüslimden bahsetmektedir. Ona göre hiç kimse bu alanları onlara tapınmak ya da Allah'ın rızasını elde etmek niyetiyle ziyaret etmeyecektir.

Savvāf'ın İbn Bāz'la dünyanın yörüngesi üzerine tartışmasına benzer bir şekilde, Cemal de, eski Vahhabi kaygılarına karşı ek bir argüman olarak, orta çağda İslam'ın bilim-teknik ve diğer kültürel alanlardaki başarılarını ve o zamanlar Müslümanların Avrupalılardan önde olduğunu ileri sürmektedir. Hem Savvāf hem de Cemal, özellikle de İbn Bāz gibi bir adamla giriştikleri tartışmada, İslam orta çağının bu büyük kültürel başarılarının yaratıcıları ve hamillerinin hepsinin Müslüman olmadığ1 gerçeğini ise, kasten görmezden gelmektedirler. Öyle ki, bu argümanlarının geçerliliğini de suya düşürmektedir. Zira, kısmen Yahudi ve Hristiyanlar da olmak üzere, çağın pek çok Müslüman alimi güne dair bir İslam anlayışı ortaya koymuşlardır, mütedeyyin Müslümanların yazıları ise oldukça tartışmaya açıktır ve hatta skandal olarak addedilmişlerdir. ${ }^{59} \mathrm{Bu}$, eski Vahhabilik anlayışında inancın mutlak katılığına dair halk dininin ve savunmacılığın, gururlu bir kültür duygusuna öncelik verdiği bilinçli ya da bilinçsiz bir girişimidir. Ülkenin teknokratik ve idari seçkinleri, onların çocukları ve öğrencilerin büyük çoğunluğu için bu girişim oldukça başarılı olabilir. Eski Vahhabiliğin temsilcileri durumunda ise (ki; 1979 Kasım ayındaki Kâbe işgalinin de gösterdiği gibi, onların da kendi çocukları vardı) ${ }^{60}$ hiçbir etkisi yoktur ya da direniş doğurmuştur.

İbn Bāz'a verdiği cevabında Cemal, Mısır'daki firavun dönemine ait eski eserlere dair uygulamalara yapılan göndermeleri dahil etmemişti. Bu bir tesadüf değildir: Her ne kadar Cemal'in teklifine yönelttiği eleştirisinde İbn Bāz bu nokta üzerine bir yorumda bulunmamış olsa da, firavun mirasının muhafazasına ilişkin herhangi bir olumlu ifadenin "firavunculuk" düşüncesinin onaylanması olarak anlaşılabileceği kendisi için açıktı. Başka bir deyişle, tarihten bir resme dayalı olan Misırlı bir milli şuurun (ki bu aydınlarda gözlemlenmekteydi, fakat henüz Misırlı kitlelerce anlaşılmamıştı) gelişimi için övgü hem Müslümanlar hem de seküler Arap milliyetçilerince kabul edilemezdi: İslam öncesi firavunların Mısır'ından duyulan gurur ve Misırlıların özel bir tarihsel sürekliliğine olan inanç, İslami tarihsel şuuru az ya da çok yerinden ediyor ve hatta Arabizm'e olan bağlılığ1 dahi sorgulanır hale getiriyordu. ${ }^{61}$

Burada, üçüncü dünya ülkelerinde milliyetçiliğin ve sekülerizmin ortaya çıkışı ya da tarihyazımsal bakımdan meşrulaştırılmasında genellikle merkezi olan bir sorunu ele almaktayız ${ }^{62}$; Kiros ve diğer kadim İran hükümdarları etrafında şekillenen kültleri, hatta en az onun kadar önemli olan İslam öncesi İran kültürünü, Şah Muhammed Rıza Pehlevî’nin gayet açık bir siyasi niyetle bunu teşvik edişini ve Şii müçtehitlerin buna nasıl cevap verdiklerini düşünelim. ${ }^{63}$

Suudi Arabistan'da, Mısır, İran ya da Lübnan'daki ('Fenikeizm') bu tür tezahürlerle uzaktan dahi karşılaştırılabilecek hiçbir entelektüel akım yoktur. Pehlevilerin yönetimi altındaki İran'ın

59 G. Strohmeier: Denker im Reich der Kalifen, Leipzig (vb.) 1979, birçok yerde

60 Bkz. J. Reissner: Die Besetzung der großen Moschee in Mekka 1979, Orient 2/1980, s. 194-203

61 Bkz. W. Ende: Arabische Nation und islamische Geschichte, Beirut ve Wiesbaden 1977, s. 87 ve 234 ve takip eden sayfa, belirtilen literatüre ek olarak; ayrıca W. Walther: Der Pharaonismus in der moł dernen ägyptischen Literatur, Martin-Luther-Universität Halle-Wittenberg, Wiss. Beiträge 1980/36 (F23), Halle 1980, s. 85-92, ve R. Wielandt: Das Bild Europäer in der moderner arabischen Erzähl- ve Theaterliteratur, Beirut ve Wiesbaden 1980, bkz. Index 'Pharaonismus'

62 B. Lewis: History. Remembered, Recovered, Invented, Priceton, N.J., 1975; D.C. Gordon: SelfDetermination and History in the Third World, Princeton 1971

63 Lewis, a.g.e., özl. s.4-7, ve W. Ende: Der schiitische Islam als politische Kraft, Iran in der Krise, Bonn 1980, s.19-35, burada s. 29 
aksine, Suud hanedanı, öngörülebilir bir gelecek için benzer eğilimlerin ortaya çıkmasıyla ilgilenemezdi. Öte yandan, İslam ve İslam öncesi (!) eserlerin keşfi, araştırılması ve nihayet restore edilmelerine yönelik bağımsız bir arkeoloji ve sanat tarihinin ortaya çıkması görünüşe göre durdurulamazdı: 1978'den bu yana, Riyad Üniversitesi Edebiyat Fakültesi'nde, şu anda yaklaşık 330 öğrenciye sahip, bağımsız bir arkeoloji bölümü bulunmaktadır. ${ }^{64}$ Bölüm, İngiltere' de eğitim görmüş olan Arkeolog Dr. Abdurrahman el-Ensārī tarafından idare edilmektedir ve yakın zamanda, kendisi tarafından yönetilen bir kazı üzerine kitap yayımlamıştır. ${ }^{65}$ Eğitim Bakanlığı ise bir süredir Müzeler ve Kadim Eserler Bölümü'ne sahiptir ve 1977'den beri 'Atlāl, Suudi Arabistan Arkeoloji Dergisi'ni (The Journal of Saudi Arabian Archeology) yayımlamaktadır. Şurası öngörülebilir ki, bir disiplin olarak İslam öncesi arkeolojisinin gelişimi - ki geleneksel İslami bakış açısına göre 'gerçek dini yasanın bilinmediği' (Cahiliye) ${ }^{66}$ bir zamanla ilgilenmektedir - ve bilimsel araştırmalarla bu geçmişin efsanevi görüntüsünün düzeltilmesi iddiası, eski Vahhabilik saflarında şikayetler ve huzursuzluğa yol açacaktır.

Arapların (sadece şiirlerinin değil) İslam öncesi tarihlerinin yüceltilmesi ve günümüze kadar uzanan tarihsel bir sürekliliğe vurgu yapılması, seküler yönelimli Arap milliyetçiliğinin kendine has özelliklerinden biridir. Örneğin bu, Baas Partisi'nin kendi rehberliğinde yapılan milli tarihyazımı için gösterdiği çabalara yansımaktadır. ${ }^{67}$ Suudi Arabistan da dahil olmak üzere, Arap Yarımadası'nın İslam öncesi tarihinin ülkenin okullarında ve üniversitelerinde nasıl ele alınacağı sorusunun, sonuçları ülke dışına taşacak tartışmalara konu olacağını varsaymak makuldür ve bu bağlamda, İslam ve milliyetçilik arasındaki ilişki sorununa, laiklik meselesine ve diğer birkaç kritik noktaya kaçınılmaz olarak değinilmektedir. Suudi Arabistan hükümeti (ki onun iyi niyeti olmaksızın arkeoloji eğitiminin ve araştırmalarının gelişimi Suudi Arabistan'da mümkün değildir ve gelecekte de mümkün olmayacaktır) diğer pek çok kültür politikası vakasında olduğu gibi, burada da manevra yapmak zorunda kalacaktır. Her ne kadar geçmişte Mekke' deki cami işgaliyle (1979) ilişkili bir gruba sempati göstermiş olduğu söylense de, ${ }^{68}$ Dini Bilimsel Araştırmalar, Fetvalar, Davet ve Dini Liderlik İdaresi'ne (el-İdāra li 'l-buhūs el-ilmīye ve'l-fetevā ve'd-da 'vā ve'l-irşād) yıllarca başkanlık yapmış olan İbn Bāz, halen resmi bir sayg1 görmektedir: 1 Mart 1982'de, Kral Hālid (ö. 13.7.1982) adına Veliaht Prens Faysal'ın elinden, 300,000 Suudi Riyali değerindeki 'Uluslararası Kral Faysal İslam'a Hizmet Ödülü’nü, altın madalya ile birlikte almıştır. ${ }^{69}$

64 Bkz. Arab News 19.4 ve 25.4.1982, her ikisinde de s. 7, ve Saudi Gazette 14.5.1982, s.5

65 Qaryat al-Fau. A Portrait of Pre-Islamic Civilization in Saudi Arabia, London (Croom Helm)

66 Bkz. mak. 'Djâhiliyya' (diğer ilişkin makalelere referanslarla) EI2, II, s. 383 ve takip eden sayfa

67 Suriye için bkz. I. Rabinovich: Historiography and Politics in Syria, Asian Affairs, 9 (old ser. 9), 1. Bölüm, 1978, s.57-66, Irak için bkz. Der Generalsekretär und die Geschichtsschreibung, Ibrahim A. El-Sheikh ve diğerleri (ed.): The Challenge of the Middle East, Amsterdam 1982, s. 161-172

68 Bkz. J. Reissner: Die Besetzung, özl. s. 196 dipnot 11 ve s. 199 dipnot 24

69 Arab News, 2.3.1982, s.1; Ibn Bāz ve Kâbe baskıncılarının lideri arasındaki değişen ilişkiler için bkz. J. Buchan: Secular and Religious Opposition in Saudi Arabia, T. Niblock (ed.): State, Society and Economy in Saudi Arabia, London 1982, s. 106-24, burada 122-23 